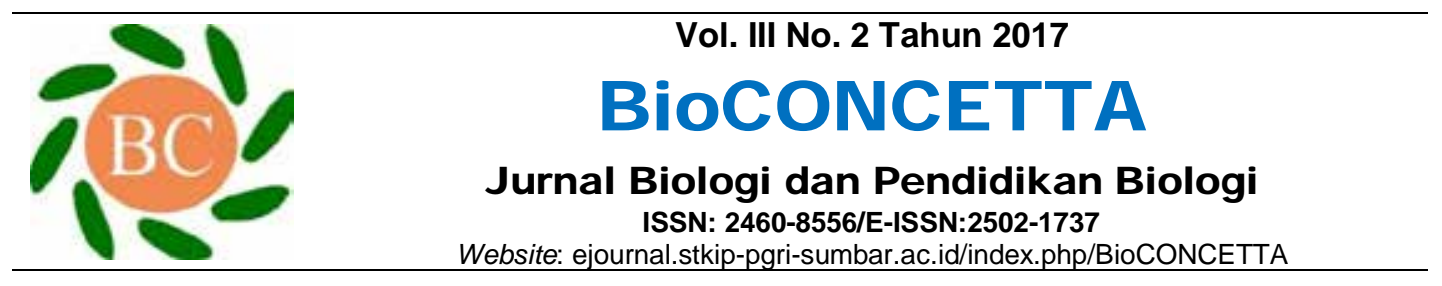

\title{
Jenis Udang Air Tawar di Salah Satu Sungai di Indonesia
}

Lora Purnamasari

Program Studi Pendidikan Biologi STKIP PGRI Sumatera Barat

Jl. Gunung Pangilun, Kota Padang, Provinsi Sumatera Barat (25137), Indonesia

E-mail: lorapurnamasri@gmail.com

\section{Info Artikel}

Sejarah Artikel

Diterima:

1 September 2017

Disetujui:

27 Oktober 2017

Dipublikasikan:

4 Desember 2017

Kata Kunci:

udang air tawar,

Macrobrachium

Keywords:

Shrimp freshwater, Macrobrachium

\begin{abstract}
Abstrak
Tujuan penelitian ini adalah untuk mengetahui jenis udang air tawar yang terdapat di salah satu sungai di Indonesia. Pengambilan sampel dilakukan di Daerah Aliran Sungai Manna yang terdiri dari Sungai Ketaman dan Sungai Langkap. Penentuan lokasi pengambilan sampel udang dilakukan secara purposiv, dilanjutkan dengan metode road sampling ke arah hulu selama 1 jam sejauh $10 \mathrm{~m}$. Hasil penelitian diperoleh udang air tawar dari famili Palamonidae, genus Macrobrachium yang terdiri dari dua spesies yaitu spesies Macrobrachium lanchesteri dan Macrobrachium sintangense. $M$. lanchesteri paling banyak ditemukan dengan jumlah 39 individu, sedangkan spesies Macrobrchium sintangense berjumlah 19 individu
\end{abstract}

\begin{abstract}
The purpose of this research is to study the species of freshwater shrimp in one of the rivers in Indonesia.Sampling was conducted in the Manna River Basin consisting of Ketaman River and Langkap River. Determination of shrimp sampling location was done purposively, followed by road sampling method upstream for 1 hour as far as $10 \mathrm{~m}$. The results obtained from freshwater shrimp from families Palamonidae, genera Macrobrachium consisted of species Macrobrachium lanchesteri and Macrobrachium sintangense. $M$. lanchesteri most commonly found with the number of thirtynine individuals, while species Macrobrchium sintangense amounted to nineteen individuals.
\end{abstract}




\section{PENDAHULUAN}

Udang air tawar dikelompokkan dalam subfilum Crustacea, kelas Malacostraca, ordo decapoda. Udang air tawar di Indonesia didominasu oleh dua famili, yaitu Palaemonidae dan Atyidae (Cai dkk., 2007; de Grave,2008). Anggota famili Palamonidae yang paling banyak ditemukan adalah dari genus Macrobrachium, yang biasa di temukan di perairan mengalir maupun menggenang, selain itu seluruh siklus hidupny aberada di air tawar.Anggota family Atyidae paling banyak ditemukan ialah dari genus Caridina, yang biasa ditemukan pada sungai yang memiliki riparian dan periran menggenang(Cai dkk., 2007; de Grave,2008; Taufik, 2011).

Secara ekologi udang air tawar berperan penting dalam mata rantai di suatu perairan (Purnamasari, 2013). Keberadaan udang air tawar sebagai dekomposer dan bioindikator kualitas lingkungan perairan (Wowor dkk., 2009; Taufik, 2011). Secara ekonomi udang air tawar memili nilai jual, karena merupakan salah satu sumber protein hewani dan telah banyak dibudidayakan.

Sebagian besar daerah aliran sungai Manna memiliki aliran yang deras, air tidak mengalir, dan air yang berarus lambat. Daerah Aliran Sungai Manna terdiri dari sungai Ketaman dan sungai Langkap. Diantara sungai Manna, sungai Langkap dan sungai Ketaman memiliki jarak yang berbeda. Antara sungai Manna ke sungai Ketaman sejauh 5 km sementara sungai Ketaman ke sungai Langkap berjarak 7 km, dan sungai Langkap kesungai Manna berjarak $2 \mathrm{~km}$. Daerah aliran sungai Manna dimanfaatkan oleh penduduk untuk mencari ikan, keperluan rumah tangga seperti mandi dan mencuci, selain itu di sepanjang pinggiran dimanfaatkan sebagai tempat pemukiman, dan perladangan. Akibat dari beberapa aktivitas yang masyarakat lakukan di sekitar sungai diduga mempengaruhi keberadaan udang air tawar.

Penelitian ini bertujuan untuk mengetahui jenis udang air tawar di daerah aliran sungai Manna Kecamatan Tanjung Sakti Kabupaten Lahat Provinsi Sumatera Selatan.

\section{BAHAN DAN METODE}

Penelitian lapangan dilakukan dari bulan Juli sampai Agustus 2015 dan Identifikasi sampai bulan 
September 2015. Pengambilan sampel dilakukan di (DAS) Daerah Aliran Sungai Manna yang terdiri dari Sungai Ketaman dan Sungai Langkap yang terdapat di wilayah Kecamatan Tanjung Sakti, Kabupaten Lahat, Provinsi Sumatera Selatan.

Alat yang digunakan dalam penelitian ini adalah hand net, bubu, jala/jaring, meteran, kacalup, termometer, kayu, tali rapia, bola pimpong, botol sampel dan alkohol 96\%. Bubu digunakan pada perairan yang tidak dapat digunakan pada perairan yang tidak dapat digunakan hand net sementara jala/jarring digunakan di perairan yang memiliki kedalaman antara $60-145 \mathrm{~cm}$. Seluruh udang yang di koleksi dimasukkan ke dalam botol sampel yang telah diberi alkohol 96\% dan diberi label.

Penentuan lokasi pengambilan sampel udang dilakukan secara purposive artinya bertujuan khusus dan dilanjutkan dengan metode road sampling ke arah hulu selama 1 jam sejauh $10 \mathrm{~m}$. Metode road sampling dilakukan dengan menggunakan hand net, jala/ jarring dan bubu. Bubu digunakan pada perairan yang tidak dapat digunakan hand net.

Semua sampel yang telah diperoleh selanjutnya diidentifikasi menggunakan kunci identifikasi berdasarkan morfologi menggunakan kunci identifikasi menurut Wowor dkk., (2004) dan Cai dkk., (2007).

\section{HASIL DAN PEMBAHASAN}

Sampel hasil tangkapan pada penelitian ini menunjukan bahwa Famili Palamonidae genus Macrobrachium dari spesies Macrobrachium lanchesteri paling banyak ditemukan dengan jumlah 39 individu, sedangkan spesies Macrobrchium sintangense berjumlah 19 individu. Hal ini ditunjukkan di Tabel 1.

Tabel 1. JumlahUdang Air Tawar yang Ditemukan pada Setiap Titik Sungai

\begin{tabular}{cccccccc}
\hline \multirow{2}{*}{ No } & \multirow{2}{*}{ Spesies } & \multicolumn{2}{c}{ Lokasi 1* } & \multicolumn{2}{c}{ Lokasi 2* } & \multicolumn{2}{c}{ Lokasi 3* } \\
\cline { 2 - 7 } & Titik 1 & Titik 2 & Titik 1 & Titik 2 & Titik 1 & Titik 2 \\
\hline 1 & M. lanchesteri & 12 & 10 & 17 & 0 & 0 & 0 \\
2 & M.sintangense & 8 & 4 & 0 & 0 & 4 & 3 \\
Jumlah individu & 20 & 14 & 17 & 0 & 4 & 3 \\
Jumlah spesies & 2 & 2 & 1 & 0 & 1 & 1 \\
\hline
\end{tabular}

Keterangan: Lokasi: 1= Sungai Manna, 2= Sungai Ketaman, 3= Sungau Langkap 
Dari data yang tercantum Tabel 1 menunjukkan bahwa hanya ditemukan dua spesies dari Famili Palamonidae Genus Macrobrachium. Macrobrachium lanchesteri paling banyak ditemukan dengan jumlah 39 individu masing-masing dari titik 1 di sungai Manna ditemukan 12 individudan titik 2 ditemukan 10 individu. Sedangkan di sungai Ketaman dititik 1 ditemukan 17 individu dan dititik 2 tidak ditemukan spesies Macrobrachium lanchesteri, begitu juga di sungai Langkap dari titik 1 dan titik 2 tidak ditentukan spesies Macrobrachium lanchesteri.

Macrobrachium sintangense ditemukan dengan jumlah 12 individu dari sungai Manna di titik 1 ditemukan 8 individu dan titik 2 ditemukan 4 individu sementara di sungai Ketaman tidak ditemukan spesies Macrobrachium sintangense sedangkan di sungai Langkap di titik 1 ditemukan 4 individu dan titik 2 ditemukan 3 individu.

Total jumlah di sungai Manna titik 1 berjumlah 20 individu dan di titik 2 berjumlah 14 individu dengan masing-masing terdapat 2 spesies di antaranya Macrobrachium lanchesteri dan Macrobrachium sintangense.

Sungai Ketaman di titik 1 berjumlah 17 individu dan terdapat 1 spesies yaitu Macrobrachium lanchesteri. Sementara di sungai Langkap di titik 1 berjumlah 4 individu dan di titik 2 berjumlah 3 individu dengan masingmasing terdapat 1 spesies yaitu Macrobrachium sintangense.

Pada hasil penelitian di dapatkan dua spesies udang iar tawar yaitu Macrobrachium lanchesteri dan Macrobrachium sintangense. Kedua spesies tersebut memiliki perbedaan pada bagian rostrum dan karpus pada kaki jalan kedua (2nd periopods).

Gigi rostrum yang dimiliki Macrobrachium sintangensetersebar merata dan ada di semua bagian rostrum, sementara gigi rostrum Macrobrachium lanchesteri tidak tersebar merata dan ada bagian yang tidak bergerigi. Karpus yang dimiliki Macrobrachium sintangense berbentuk panjang dan langsing serta memiliki panjang karpus yang lebih pendek dibanding chela, sedangkan Macrobrachium lanchestri karpus lebih panjang di banding chela.

$\begin{array}{ccc}\text { Spesies udang air tawar } \\ \text { Macrobrachium lanchesteri } & \text { paling } \\ \text { banyak ditemukan pada } & \text { lokasi } \\ \text { penelitian. } & \text { Udang } & \text { spesies }\end{array}$


Macrobrachium lanchesteri merupakan spesies bersifat invasif. M.lanchesteri diduga masuk keperairan jambi bersamaan dengan kegiatan perikanan yang mengintroduksi perikanan. Kemampuan M. lanchesteri dapat bertahan pada kondisi lingkungan yang ekstrim sehingga keberdaannya dapat mengancam spesies asli. Spesies M. lanchesteri tersebar di Thailand (Wowor dkk., 2009).

\section{SIMPULAN}

Dari hasil penelitian didapatkan dua spesies udang air tawar yang ditemukan yaitu Macrobrachium lanchesteri dan Macrobrachium sintangense.

\section{DAFTAR PUSTAKA}

Cai Y, Ng PKL, Choy S. 2007. Freshwater Shrimp of The Family Atyidae (Crustacea: Decapoda: Caridea) from Peninsular Malaysia and Singapore. Raff. Bull. Zool. 55:277-309.

de Grave S, Cai Y, Anker A. 2008. Global Diversity of Shrimp
(Crustacea: Decapoda: Caridea) in Freshwater. Freshwater Animal Diversity Assesment 595: 287:293.

Purnamasari, L. 2013. Keanekaragaman Udang Air Tawar Pada Berbagai Tipe Habitat di Provinsi Jambi[Tesis] Bogor. FakultasMatematika dan IlmuPengetahuanAlam, InstitutPertanian Bogor.

Taufik. 2010. Keanekaragaman Udang Air Tawar di Danau Kerinci Provinsi Jambi [Tesis] Bogor. Fakultas Matematika dan Ilmu Pengetahuan Alam, Institut Pertanian Bogor.

Wowor D, Cai Y, Ng PKL. 2004 .Crustacea : Decapoda, Caridae. Di dalam; Yule CM, Sen YH, editor.Freshwater Invertebrates of the Malaysian Region. Kuala Lumpur. Academy of Science Malaysia : 337-356.

Wowor D, Muthu V, Meier R, Balke M, Cai Y, Ng PKL. 2009. Evolution of life hystory traits in asian freshwater prawns of genus Macrobrachium (Custacea: Decapoda: Palaemonidae) based on multilocus molecular phylogenetic analysis. Mol Phylogenetic and Evol 52: 340350 . 